\title{
Thrips of the Sagebrush-Grass Range Community in West-Central Utah
}

\author{
WARD M. TINGEY' ${ }^{2}$ CLIVE D. JORGENSEN, \\ AND NEIL C. FRISCHKNECHT
}

Research Associale, University of Arizona, Tucson; Associate Professor of Zoology, Brigham Young University, Provo, Utah; and Principal Plant Ecologist, Intermountain Forest and Range Experiment Station, Provo, Utah.

\section{Highlight}

Twenty species of thrips (Thysanoptera) were collected from big sagebrush, rubber rabbitbrush, antelope bitterbrush, and crested wheatgrass on west-central Utah sagebrush-grass rangelands. Twelve species of thrips were collected from crested wheatgrass, 10 from rubber rabbitbrush, 10 from big sagebrush, and three from antelope bitterbrush. Three species (Anaphothrips tricolor, Chirothrips aculeatus and Chirothrips simplex) were new distribution records for Utah. Thrips damage was not apparent to any of the host species examined during this study, but Anaphothrips zeae, Aptinothrips rufus, and Frankliniella occidentalis are potential pests of range species and merit further study.

Most attempts to increase the carrying capacity of sagebrush-grass

1 This work was supported, in part, by a grant (12-11-204-31) to Brigham Young University from the Intermountain Forest and Range Expcriment Station, Forest Service, U.S. Department of Agriculture. Received July 29, 1971.

2 Specimens were identified by Tokuwo Kono, California Department of Agriculture. Kellie O'Neill, U.S. Department of Agriculture, Entomology Research Division; and J. G. Watts, New Mexico State University. ranges have included seeding desirable plant species (Stoddard, 1946; Plummer et al., 1955). Little has been done to develop a sound understanding of the interacting systems responsible for maintaining these ranges, although this approach has been recognized by some as being necessary (Humphrey, 1962; Manis, 1967). Since the interactions among species need to be studied, it is clear that the niches occupied by insects should be examined.
Insects, aided by their high rate of reproduction, rapid dispersal, and sometimes rapacious appetites are vital members of almost all terrestrial communities, and may ultimately determine the fate of some plants in their respective communities. The importance of insects on western North America ranges has been reported by Knowlton (1966), Manis (1967), and Jorgensen and Tingey (1968).

Thrips (Thysanoptera) are small slender insects betwecn about 0.5 and $5.0 \mathrm{~mm}$ in length (Fig. 1). Two pairs of wings may or may not be present, depending on the species and stage of development. If present, the wings are long, slender, often fringed with long hairs and with few or no recognizable veins. Food is obtained for all stages in the life cycle by sucking out the contents of plant cells, or by sucking the body contents of other insects and mites. Most of the approximately 1500 species are phytophagous and found on a wide variety of host species over most of the world where they are sometimes serious pests. Some are predacious, or at least partially so, while others are found among plant detritus where their feeding 


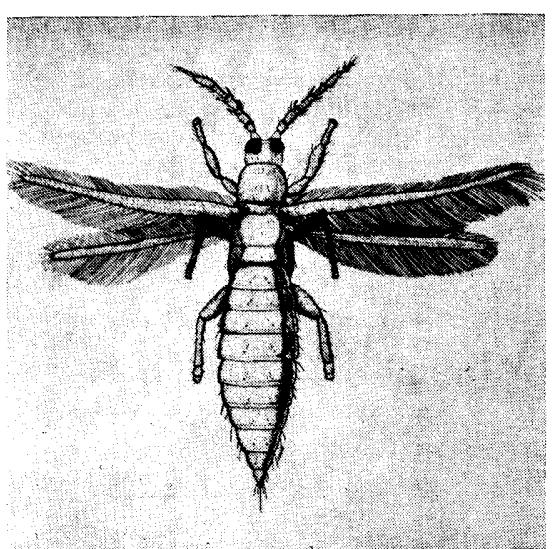

Fig. 1. Dorsal view of a thrips, Frankliniella occidentalis.

habits are not clearly known. Damage to plants is largely a matter of killing localized cells, although many species are found in the flowering structures and sometimes cause damage to the developing seeds or fruits.

Bailey and Knowlton (1949) listed only 17 species of thrips from Utah, but many of them were reported from plants within the sagebrushgrass ranges. Knowlton and Thomas (1933) suggested earlier that the damage to some of the range plants by thrips was more serious in Utah than was usually supposed. Since phytophagous thrips have been reported from range plants where they are potentially damaging, it was necessary to closely examine the niches they occupied. This paper discusses the thrips associated with three economically important native shrubs and one grass seeded into the sagebrush-grass community in west-central Utah. The four plant species were: big sagebrush (Artemisia tridentata Nutt), rubber rabbitbrush (Chrysothamnus nauseosus (Pall.) Britt), antelope bitterbrush (Purshia tridentata (Pursh) DC), and crested wheatgrass (Agropyron desertorum (Fisch.) Schult).

\section{Study Sites}

All of the study sites were located near or in the southeast portion of Tooele Co., Utah, at an clevation

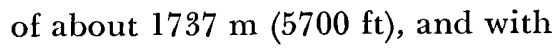
an annual rainfall of about $33 \mathrm{~cm}$
(13 in). Four sites were selected for each host plant, totaling 16 .

\section{Crested Wheatgrass}

Site 1, pasture no. 27 at the Benmore Experimental Range, was predominantly crested wheatgrass. Site 2, an unfenced area at the Benmore Experimental Range, included crested wheatgrass and big sagebrush as co-dominants. Site 3 , located $10 \mathrm{~km}(6.2 \mathrm{mi})$ west of Eureka, Juab Co., Utah, included essentially only crested wheatgrass which had been seeded after the sagebrush had been removed. Site 4, a Utah State University experimental pasture located about 10 $\mathrm{km}(6.2 \mathrm{mi})$ south of Eureka, was essentially a pure stand of crested wheatgrass.

\section{Big Sagebrush}

Site 1, pasture no. 2 at the Benmore Experimental Range, was predominantly big sagebrush. Site 2 occupied the same area as crested wheatgrass site 2 . Site 3 , about 11 $\mathrm{km}(6.8 \mathrm{mi})$ west of Eureka, was nearly a pure stand of big sagebrush. Growth of the big sagebrush in site 3 was unusually vigorous, some plants being about $1.8 \mathrm{~m}(6$ ft) high. Site 4 , about $5 \mathrm{~km}(3.1 \mathrm{mi})$ south of Eureka, included big sagebrush and antelope bitterbrush as co-dominants.

\section{Rubber Rabbitbrush}

Site 1, pasture no. 19 at the Benmore Experimental Range, included vigorously growing rubber rabbitbrush in the washes. Site 2 was located in a wash of an unfenced area at the Benmore Experimental Range. Site 3 was located about $5 \mathrm{~km}$ (3.1 mi) north of Vernon, Tooele Co., Utah, where rubber rabbitbrush was co-dominant with greasewood (Sarcobatus vermiculatus (Hook.) Torr.) along the roadside adjacent to a sizeable wash. Site 4 was located in a Utah State University pasture about $10 \mathrm{~km}(6.2$ mi) south of Eureka. The only other plant species present in substantial quantity at site 4 was cheatgrass (Bromus tectorum L.).

\section{Antelope Bitterbrush}

Site 1 was located about $8 \mathrm{~km}$ $(5.0 \mathrm{mi})$ west of Eureka, where antelope bitterbrush was small and rather widely scattered. Site 2 was in the same area as big sagebrush site 4 . Site 3 was about $5 \mathrm{~km} \mathrm{(3.1}$ mi) east of Eureka where antelope bitterbrush was rather dense, and with vigorous growth. Site 4, similar to site 3 , was located about 8 $\mathrm{km}(5.0 \mathrm{mi})$ east of Eureka.

\section{Methods}

Sixty-five sweeping and 65 Berlese collections were made during the summers (June-September) of 1966 and 1967 from the study sites. Foliage and inflorescence were excised with as little disturbance to resident insects as possible, then sealed in paper bags. Litter from beneath the respective host plants was also sealed in paper bags. These materials were then placed about 10 $\mathrm{cm}$ (4.0 in) deep in Berlese funnels for $48-56 \mathrm{hr}$, from which the thrips collected in an $\mathrm{AGA}^{3}$ solution. Specimens were then cleared in cold (4C) lacto-phcnol for 1-3 weeks and then mounted in Hoyers media.

\section{Results}

Twenty species were collected (seven were undescribed), although only eight were collected in substantial numbers (Table 1). Specimens from all sites were pooled for analyses, since individual collections were often rather variable. The Berlese sampling method raised questions with regard to its quantitative accuracy; thus, the analyses were based largely on the incidence of occurrence.

Frankliniella occidentalis, F. min$u$ ta, and a new species of Sericothrips were most frequently collected in the 65 samples. Nine species were restricted to one host species while only one was collected from all four. Another nine species were collected only from foliage

${ }^{3}$ AGA is a preservative especially adapted for thrips. It includes 8 parts $95 \% \mathrm{EtOH}, 5$ parts distilled water, 1 part glycerin, and 1 part glacial acetic acid. 
Table 1. Number and percentage of occurrences from 65 collections of foliage and litter for each thrips species.

\begin{tabular}{|c|c|c|c|c|c|c|c|c|c|c|}
\hline \multirow[t]{2}{*}{ Thrips species } & \multicolumn{2}{|c|}{$\begin{array}{l}\text { Agropyron } \\
\text { cristatum }\end{array}$} & \multicolumn{2}{|c|}{$\begin{array}{c}\text { Artemisia } \\
\text { tridentata }\end{array}$} & \multicolumn{2}{|c|}{$\begin{array}{l}\text { Chrysothamnus } \\
\text { nauseosus }\end{array}$} & \multicolumn{2}{|c|}{$\begin{array}{c}\text { Purshia } \\
\text { tridentata }\end{array}$} & \multicolumn{2}{|c|}{ Percentage } \\
\hline & Fol. & Lit. & Fol. & Lit. & Fol. & Lit. & Fol. & Lit. & Fol. & Lit. \\
\hline Aeolothrips duvali Moulton & 1 & 0 & 0 & 0 & 1 & 0 & 0 & 0 & 100 & 00 \\
\hline Aeolothrips fuscus Watson & 0 & 0 & 0 & 0 & 7 & 0 & 0 & 0 & 100 & 00 \\
\hline Anaphothrips tricolor Moulton & 1 & 0 & 1 & 0 & 0 & 0 & 0 & 0 & 100 & 00 \\
\hline Anaphothrips zeae (Moulton) & 3 & 1 & 0 & 0 & 0 & 0 & 0 & 0 & 75 & 25 \\
\hline Aptinothrips rufus (Gmelin) & 3 & 0 & 1 & 1 & 2 & 0 & 0 & 0 & 86 & 14 \\
\hline Aptinothrips rufus stylifera Trybom & 1 & 1 & 0 & 0 & 0 & 1 & 0 & 0 & 67 & 33 \\
\hline Chirothrips aculeatus Bagnall & 1 & 0 & 0 & 0 & 0 & 0 & 0 & 0 & 100 & 00 \\
\hline Chirothrips simplex Hood & 2 & 0 & 0 & 0 & 0 & 0 & 0 & 0 & 100 & 00 \\
\hline Frankliniella minuta Moulton & 0 & 0 & 5 & 0 & 7 & 0 & 0 & 0 & 100 & 00 \\
\hline Frankliniella occidentalis (Pergande) & 1 & 0 & 5 & 1 & 13 & 0 & 0 & 1 & 90 & 10 \\
\hline Frankliniella sp. & 1 & 0 & 3 & 0 & 0 & 0 & 0 & 0 & 100 & 00 \\
\hline Frankliniella sp. & 0 & 0 & 3 & 0 & 0 & 0 & 0 & 0 & 100 & 00 \\
\hline Haplothrips sonorensis Stannard & 0 & 1 & 0 & 0 & 0 & 0 & 0 & 0 & 00 & 100 \\
\hline Haplothrips sp. & 0 & I & 0 & 0 & 0 & 0 & 0 & 0 & 00 & 100 \\
\hline Leptothrips sp. & 0 & 0 & 1 & 0 & 0 & 0 & 0 & 0 & 100 & 00 \\
\hline Oedaleothrips sp. & 1 & 2 & 0 & 0 & 0 & 1 & 0 & 0 & 25 & 75 \\
\hline Rhopalandrothrips corni Moulton & 0 & 0 & 0 & 0 & 0 & 0 & 0 & 1 & 00 & 100 \\
\hline Sericothrips sp. & 0 & 0 & 5 & 1 & 1 & 0 & 0 & 1 & 75 & 25 \\
\hline Sericothrips sp. & 0 & 0 & 2 & 1 & 7 & 3 & 0 & 0 & 69 & 31 \\
\hline Thrips tabaci (Lindeman) & 0 & 0 & 2 & 0 & 2 & 0 & 0 & 0 & 100 & 00 \\
\hline Percentage (between habitats) & 71 & 29 & 89 & 11 & 89 & 11 & 00 & 100 & 82 & 18 \\
\hline Percentage (among hosts) & & 21 & & 32 & & 45 & & 02 & & 100 \\
\hline
\end{tabular}

and seven were found in both foliage and litter. Crested wheatgrass had the most diverse fauna (12 species), whereas only three species were collected from antelope bitterbrush.

Those species that occurred in at least $5 \%$ of the 65 collections were further analyzed for host and habitat preferences. This resulted in an analysis of eight species $(A$. rufus, $F$. minuta, $F$. occidentalis, Frankliniella sp., Oedaleothrips sp., Sericothrips sp., Sericolhrips sp., $T$. tabaci). Aptinothrips rufus and Oedaleothrips sp. preferred crested wheatgrass, Sericothrips sp. preferred big sagebrush and $F$. occidentalis and Sericothrips sp. preferred rubber rabbitbrush. Host preferences could not be determined for $F$. minuta, Frankliniella sp., and T. tabaci. Among these eight species only Oedaleothrips sp. showed a habitat preference for litter over foliage (Table 1).

Seasonal changes in the relative numbers of thrips were determined simply by computing an index of the number of times a species was collected divided by the number of collection attempts. The index varied from $0-1$ as the density of thrips increased. Although these analyses were based on an assumption of random distribution, which was not demonstrated, they were used to indicate the direction that the population density was moving, and with considerable confidence since the results were not related to real number densities. Changes in the relative densities of the eight most abundant thrips are presented in Table 2.

\section{Discussion}

This discussion is restricted to thrips species that are considered economically or ecologically important to the host species studied.

Anaphothrips zeae was reported from agricultural grasses in Utah by Bailey and Knowlton (1949) and Bailey (1957). It was restricted to crested wheatgrass in this study, where it was most abundant in July. Most species of Anaphothrips inhabit grass and sod, where they can cause considerable damage to small

Table 2. Indexes of relative abudance for the pooled 1966 and 1967 collections of thrips.

\begin{tabular}{llllc}
\hline \hline \multirow{2}{*}{ Thrips species } & \multicolumn{4}{c}{ Relative abundance index } \\
\cline { 2 - 5 } & June & July & August & September \\
\hline Aeolothrips fuscus & $.50 \mathrm{a}$ & .13 & .26 & .00 \\
Frankliniella minuta & .07 & .00 & .08 & $1.00^{\mathrm{a}}$ \\
Frankliniella occidentalis & .18 & .27 & .12 & $.83^{\mathrm{a}}$ \\
Frankliniella sp. & $.27 \mathrm{a}$ & .14 & .00 & .00 \\
Oedaleothrips sp. & .00 & .11 & $.27 \mathrm{a}$ & .00 \\
Sericothrips sp. & .07 & $.21^{\mathrm{a}}$ & .17 & .00 \\
Sericothrips sp. & .26 & $.36^{\mathrm{a}}$ & .17 & .17 \\
Thrips tabaci & $.21 \mathrm{a}$ & .07 & .00 & .00
\end{tabular}

${ }^{a}$ Month of peak abundance. 
grains and grasses in seasons of high densities (Bailey 1957). Watts and Bellotti (1967) found A. zeae damaging several species of Agropyron in New Mexico, with a resultant loss in stand vigor and productivity; however, its rather low rate of occurrence on crested wheatgrass in this study indicates a minimal damage potential.

Aptinothrips rufus was also reported from Utah by Bailey and Knowlton (1949) and Bailey (1957). It was collected most frequently from crested wheatgrass and sod, and Speyer (1935) lists Agropyron as its preferred host in Europe. Bailey (1948) found it throughout the year on a variety of grasses and grains in North America. He also reported that larvae reached their peak abundance in May in permanent pastures, lawns, and uncultivated areas, but since normal cultivation practices kept the population size low and dispersal was limited because they had no wings, they were of little importance to agriculture. In rangelands, the restricting effects of cultivation are limitcd and populations of this thrips could conceivably rise high enough to cause considerable host damage.

Chirothrips aculeatus has been reported from Europe, California, Oregon, and Washington by Bailey (1957), but this is its first reported occurrence from Utah, where it was collected only once from crested wheatgrass. Immature stages of all Chirothrips appear to be obligate parasites of various grasses (Watts, 1965). Bailey (1948) reported extensive damage to grain and experimental plots of Festuca in California. Although this thrips has shown high damage potential in agriculture, its paucity suggests minimal damage potential in sagebrush-grass ranges.

Chirothrips simplex has been reported from Colorado, Illinois, and Nebraska by Hood (1927), but not from Utah until it was collected twice from crested wheatgrass. Although this species apparently has no history of causing damage to grasses, its close relative (Chirothrips falsus Priesner) has caused considerable damage to black grama (Bouteloua eriopoda Torr.) and crested wheatgrass in New Mexico (Watts, 1965). Due to its low rate of occurrence, it is not likely that C. simplex will become a serious problem to crested wheatgrass in west-central Utah ranges.

Frankliniella occidentalis was reported from big sagebrush and rubber rabbitbrush in Utah by Knowlton and Thomas (1933). Bailey (1957) included most of western North America and Mexico in its range. It was collected most frequently from rubber rabbitbrush in July. This species is known to cause considerable damage through feeding, and under some conditions, transmits plant viruses (Bailey, 1938). Ferguson et al. (1963) reported that $F$. occidentalis was responsible for more flower damage and subsequent seed loss to antelope bitterbrush than any other insect species. Because of its demonstrated damage potential, this thrips may become an important factor in the success of antelope bitterbrush.

Several additional species, not collected in this study, have been reported from the same hosts by others:

Big sagebrush

Anaphothrips obscurus (Muller) (Knowlton and Thomas, 1933)

Frankliniella moultoni Hood (Knowlton and Thomas, 1933)

Frankliniella tritici (Fitch) (Knowlton and Thomas, 1933)

Haplothrips mali (Fitch) (Knowlton and Thomas, 1933)

Odontothrips lati (Haliday) (Bailey and Knowlton, 1949)

Rubber rabbitbrush

Aeolothrips fasciatus (Linn.) (Knowlton and Thomas, 1933)

Sericothrips chrysothamni Hodd (Bailey, 1957)

Thrips abdominalis (Crawford) (Bailey and Knowlton, 1949)

Anaphothrips zeae, Aptinothrips rufus, and Frankliniella occidentalis merit additional study because they have been reported as being injurious to the specific or closely related hosts sampled in this study (Speyer, 1935; Ferguson et al., 1963; Watts and Bellotti, 1967). The fact that crested wheatgrass, which is so important to sagebrush-grass ranges in Utah, had the greatest number of potentially damaging thrips species associated with it should provide the focus for future research. Since thrips are sucking insects and cause considerable damage to foliage and sometime seeds, it is possible that they may decrease the grazing potential of crested wheatgrass stands by limiting production of seed required for natural re-seeding. All of the other species reported probably have marginal damage potential because of their low levels of occurrence.

\section{Literature Cited}

Bailey, S. F. 1938. Thrips of economic importance in California. Calif. Agr. Exp. Sta. Circ. 346:1-77.

BaIley, S. F. 1948. Grain and grass infesting thrips. J. Econ. Entomol. 41:701-706.

Bailey, S. F. 1957. The thrips of California. Part 1-Suborder Terebrantia. Bull. Calif. Insect Surv. 4: 143-220.

Bailey, S. F., and G. F. KNowlton. 1949. The Thysanoptera of Utah. Proc. Entomol. Soc. Wash. 51:231234.

Ferguson, R. B., M. M. Furniss, AND J. V. Basille. 1963. Insects destructive to bitterbrush flowers and seeds in southwestern Idaho. J. Econ. Entomol. 56:459-462.

Hood, J. D. 1927. New Thysanoptera from the United States. J. New York Entomol. Soc. 35:123-142.

Humphrey, R. R. 1962. Range Ecology. Ronald Press, New York: 234 p.

Jorgensen, C. D., And W. M. Tingey. 1968. Insects of the sagebrush-grass community in Utah. Unpubl. Rpt. to Intermountain Forest and Range Experiment Station, Ogden, Utah. $18 \mathrm{p}$.

Knowlton, G. F. 1966. Rangeland entomology-an important problem of the west. Utah St. Univ. Exp. Sta., Entomol. Mimeo Ser. 84:1-5.

Knowlton, G. F., and W. L. Thomas. 1933. Food plants and distribution of some Utah Thysanoptera. Can. Entomol. 65:114-117.

Manis, H. C. 1967. Rangeland entomology. Presented at 51 st Ann. Mtgs. 
of Pacific Br. Entomol. Soc. Amer. Speyer, E. R. 1935. The genus Ap7 p.

Plummer, A. P., A. C. Hull, G. StewART, AND J. H. Robertson. 1955. Seeding rangelands in Utah, Nevada, southern Idaho, and western Wyoming. U.S. Dep. Agr. Handbook 71. 73 p. tinothrips Haliday (Thysanoptera: Terebrantia). Trans. Roy. Entomol. Soc. London 83:483-508.

StodDARd, L. A. 1946. Seeding arid ranges to grass with special references to precipitation. Utah Agr. Exp. Sta. Circ. 122. 27 p.
Watts, J. G. 1965. Chirothrips falsus Priesner on black grama grass. Bull. New Mexico Agr. Exp. Sta. 499. $20 \mathrm{p}$.

Watts, J. G., And A. C. Bellotti. 1967. Some new and little-known insects of economic importance on range grasses. J. Econ. Entomol. 60: 961-963. 